\title{
ЛІТЕРАТУРОЗНАВСТВО
}

\section{„DRWAL NA PUSTYNI”. O KONDYCJI WSPÓLCZESNEGO UKRAIŃSKIEGO PISARZA: JEGO WIZERUNKU ORAZ ROLI W PROCESIE LITERACKIM}

\author{
ANNA HORNIATKO-SZUMILOWICZ \\ Uniwersytet Szczeciński, Szczecin — Polska \\ „ЛІСОРУБ У ПУСТЕЛІ”. ПРО СТАТУС СУЧАСНОГО \\ УКРАЇНСЬКОГО ПИСЬМЕННИКА: ЙОГО ПОРТРЕТ \\ ТА РОЛЬ У ЛІТЕРАТУРНОМУ ПРОЦЕСІ
}

\author{
АННА ГОРНЯТКО-ШУМІЛОВИЧ \\ Щецінський університет, Щецін - Польща
}

АНОТАЦІЯ. Пропонована стаття є спробою дослідити особливості онтології українського письменника в сучасному літературному процесі. В основі роботи - роздуми про специфіку художнього життя постмодерністського творця, типові риси його “обличчя”, позицію та роль у найновішій українській літературі.

\section{„WOOD CUTTER IN THE DESERT”. THE STATE OF A MODERN UKRAINIAN WRITER: HIS FACE AND ROLE IN THE LITERARY PROCESS}

\section{ANNA HORNIATKO-SZUMIŁOWICZ \\ Szczecin University, Szczecin - Poland}

ABSRACT. The article is an attempt to investigate the activity of a Ukrainian writer in modern literary process. The basis of investigation is the reflections on the peculiarities of a postmodern writer's artistic life, his typical image and role in new Ukrainian literature.

$\mathrm{I}$

ntrygująca, oksymoroniczna skądinąd fraza „drwal na pustyni” pojawiła się w tytule znakomitej książki prozaika ukraińskiego Wołodymyra Danyłenki, który z kolei zapożyczył termin z jednej prac teoretycznych Ortegi y Gasseta ${ }^{1}$. W studium Danyłenki, traktującym o specyfice współczesnego procesu literackiego na Ukrainie, pisarz próbuje dociec, dlaczego w dwadzieścia lat po proklamowaniu niezależności, ukraiński czytelnik nie czyta rodzimych książek. Autor przytacza opinie, zamieszczone na łamach jednej z ukraińskich gazet, rzekomo Ukraina pozbawiona jest twórców tej skali talentu, co w Rosji czy Europie, a sama przypomina ,jałową pustynię"2. Danyłen-

${ }^{1}$ Х. Ортега-і-Гасет, Думки про роман, перекл. з іспанської В. Сахна, [у:] Вибрані твори, Київ 1994, с. 273-305.

${ }^{2}$ В. Дан иленко, Лісоруб у пустелі. Письменник і літературний процес, Київ 2008, с. 113. 
ko porównuje ukraińskiego twórcę do „drwala na pustyni”, gdzie nikomu nie są potrzebne doświadczenie i umiejętności rębacza drzew i przekonuje: „Na Ukrainie zawsze byli utalentowani pisarze, muzycy, aktorzy. [...]. Lecz dopóki na bezwodnej pustyni nie wyrosną drzewa [tu: oczywista metafora świadomego czytelnika - A. H.-Sz.], dopóty nie będzie potrzebny drwal z ostrą siekiera, nawet jeśli posiada tors Arnolda Schwarceneggera" 3 .

Rodzi się zatem pytanie o kondycję współczesnego pisarza ukraińskiego, jego rolę i pozycję w niepodległym już kraju.

Wizerunek twórcy jest ściśle powiązany z wizerunkiem literatury przezeń tworzonej. Poziom artystyczny, miara talentu, stopień świadomości społecznej i narodowej twórcy, czy raczej twórców, warunkują poziom i odpowiedni rozwój rodzimej spuścizny literackiej.

Do czasu odzyskania przez Ukrainę niepodległości w roku 1991 literatura pozostawała w służbie narodu, o czym niejednokrotnie pisali ukraińscy twórcy, literaturoznawcy, działacze kultury. Znany ukraiński krytyk Mychajło Słaboszpycki ${ }^{4}$ słusznie twierdzi, iż na Ukrainie w czasach jej bezpaństwowości literatura zawsze była czymś więcej, niż tylko literaturą, ponieważ ciążył na niej obowiązek uświadamiania i wychowania w duchu narodowym, natomiast pisarz ukraiński pełnił funkcje szerzyciela idei narodowej, działacza państwowego, kaznodziei, nauczyciela, wychowawcy i już w ostatniej kolejności miał przywilej bycia pisarzem.

Ukraińska literatura już prawie dwadzieścia lat powstaje, przynajmniej teoretycznie, w warunkach wolnego społeczeństwa, wolności słowa. Taki stan rzeczy przyniósł wiele orzyści, ale i niemało strat, tym bardziej, iż dokonywane były pewne wybory i preferencje czytelnicze nie zawsze korzystne dla rozwoju kultury narodowej.

Twórca najnowszej literatury ukraińskiej to twórca okresu postmodernistycznego, przy czym o różnych twarzach. Albowiem biorąc pod uwagę fakt, iż w epoce postmodernistycznej istnieją jednocześnie różne struktury literackie (kierunki, prądy), współistnieją różne dyskursy, oczywiste jest, iż w ramach postmodernistycznej metody (jako systemu światopoglądowego) funkcjonują różne ugrupowania, generacje.

I tak, współczesny ukraiński prozaik Wołodymyr Jeszkiliew ${ }^{5}$ — jeden z inicjatorów wydania „Małej ukraińskiej encyklopedii aktualnej literatury” Plerom a 3`98, proponuje pokoleniową zasadę podziału współczesnych twórców-postmodernistów, według której wyraźnie zarysowuje się podział na dwa okresy: lat osiemdziesiątych (ukr. „вісімдесятники”) oraz dziewięćdziesiątych. (ukr. „дев яностники”). Do pierwszej generacji pisarz zalicza m.in. Jurija Andruchowycza, Jewhena Paszkowskiego, Wiktora Neboraka, Ołeksandra Irwancia, do drugiej - Jurija Izdryka, Tarasa Prochaśkę, Iwana Andrusiaka, Romana Kucharuka i in.

Według Natalki Biłocerkiweć, Łesi Demskiej i Wołodymyra Danyłenki głównym kryterium systematyzacji współczesnej prozy winien być czynnik terytorialny. Danyłenko, nie odrzucając pokoleniowego kryterium podziału pisarzy, rozróżnia dwie opozycyjne, jego zdaniem, szkoły: żytomierską (Wiaczesław Medwid', Jewhen Paszkowski, Mykoła Zakusyło, Jurko Gudź) oraz galicyjską (Andruchowycz, Jurij Wynnyczuk, Jeszkiliew, Izdryk, Prochaśko i in.). O ile szkoła galicyjska absolutyzuje formalistyczne poszukiwania oraz stylizację na już istniejące wzorce literackie, o tyle żytomierska zwrócona jest ku poszukiwaniom własnych podstaw, ku poruszaniu egzystencjalnych problemów jednostki, twórczej obserwacji miłości, strachu

${ }^{3}$ Tamże, c. 116.

${ }^{4}$ М. Сла бошпицьки й, За гамбурзьким рахунком. Читаџькі маргіналії та варіації на тему Павла Загребельного, Київ 2004, с. 161.

5 Плерома 3'98. Мала украӥнська енциклопедія актуальної літератури, Івано-Франківськ 1998, c. 39. 
i śmierci ${ }^{6}$. Badacz twierdzi również, iż proza pokolenia epoki ,post” prawie w całości wywodzi się od Hryhorija Tiutiunnyka oraz Walerego Szewczuka ${ }^{7}$.

Natalka Biłocerkiweć ${ }^{8}$, kierując się tym samym kryterium terytorialnym, rozróżnia szkoły galicyjsko-stanisławowską (Andruchowycz, Wynnyczuk, Prochaśko, Izdryk) oraz kijowsko-żytomierską (Medwid', Paszkowski, Lubow Ponomarenko, Jewhenija Kononenko, Wołodymyr Dibrowa, Oksana Zabużko, Ołeś Ulianenko, Bohdan Żołdak). Badaczka kładzie szczególny nacisk na odmienne typy bohaterów. O ile dla szkoły galicyjsko-stanisławowskiej charakterystyczny bohater to wyrafinowany inteligent, skłonny do filozofowania i refleksji, o tyle dla kijowsko-żytomierskiej - będzie to osobowość marginesowa, obciążona patologiczną świadomością. Zgodnie z badaczką, gra oraz ironia szkoły galicyjsko-stanisławowskiej stoi w wyraźnej opozycji do postrzegania świata przez pryzmat tragizmu przez przedstawicieli szkoły kijowsko-żytomierskiej. Charczuk ${ }^{9}$ słusznie zwraca uwage na pewne nieprawidłowości w powyższej klasyfikacji. I tak, soc-artowskie opowiadania ze zbioru Żołdaka Wołowina oraz ironiczny sceptycyzm Dibrowy w powieści Bur$d y k$ zdają się nie pasować do założeń szkoły kijowsko-żytomierskiej. Podobnie trudno nazwać, zdaniem badaczki, „wyrafinowanymi inteligentami” wiecznie pijanych bohaterów Rekreacji Andruchowycza.

Lwowska badaczka Demska rozróżnia natomiast trzy szkoły: charkowską (wyłącznie poetycką), kijowską oraz lwowsko-frankowską. Badaczka twierdzi, iż o ile ,pokolenie barykad” (Andruchowycz, Paszkowski, Zabużko, Ihor Rymaruk, Ołeh Łyszeha i in.) wykonało swoją misję: wywalczenie praw i swobód jednostki oraz swobody słowa, o tyle ,pokolenie ruin” (Serhij Żadan, Jurij Bedryk, Andrij Kokotiucha, Prochaśko, Roman Skyba i in.) powołane jest, by ofiarować nowemu państwu nową literaturę, przełamać stare tradycje i stworzyć nowe". O ile szkoła kijowska modyfikuje tradycje powieści realistycznej, o tyle lwowsko-frankowska czerpie inspiracje z symboliki wielkiego mitu ${ }^{10}$.

Jeszcze inny podział zaproponowała Charczuk ${ }^{11}$, dzieląc pisarzy lat 80. i 90. XX w. na prozaików świadomie zwróconych ku tradycji europejskiej (ukr. „західники”), takich jak Andruchowycz, Zabużko, Mykoła Riabczuk i in., oraz tych, którzy „kładą nacisk na koloryt narodowy i wieś jako metaforę” (ukr. „грунтівці”). Ci drudzy to, między innymi, Medwid, Paszkowski, Wasyl Herasymiuk. Idąc dalej badaczka zauważa, iż zasadne jest mówienie o pokoleniu postepoki czy epoki ,post” jako o pokoleniu postradzieckim, postkolonialnym, postczarnobylskim, postchrześcijańskim, postmodernistycznym, a w sumie apokaliptycznym. Umożliwia to, jej zdaniem, postrzeganie jako całości pokoleń literackich lat osiemdziesiątych i dziewięćdziesiątych XX w., które, nie zważając na pewne różnice (pierwsi dorastali jeszcze w atmosferze Ukrainy Radzieckiej, drudzy teoretycznie w niepodległej już ojczyźnie), więcej łączy, niż dzieli ${ }^{12}$.

O cechach wspólnych literackich pokoleń lat 80. i 90. pisze również Wołodymyr Danyłenko. Wykazując między nimi pewne różnice (,wisimdesiatnyky” — ,pokolenie konającego totalitaryzmu”, „bezceremonialni chuligani, którzy swoim prze-

${ }^{6}$ В. Дан иленко, Золота жила украӥнської прози, [в:] Вечеря на дванадиять персон: Житомирська прозова школа, упор., передм., літ. ред. В. Даниленка, Київ 1997, с. 10-11.

${ }^{7}$ В. Даниленко, Історія одного ісходу, [в:] його ж, Квіти в темній кімнаті. Сучасна українска новела, Київ 1997, s. 9.

${ }^{8}$ Н. Білоцерківець, Література на роздоріжжі, [в:] „Критика”, 1997, № 1, с. $28-29$.

9 Р. Харчук, Покоління постепохи, [в:] „Дивослово”, 1998, № 1, с. 10.

10 Л. Демська, Зона изілковитої свободи, [в:] „Знак”, 1997, № 1, с. 1.

${ }^{11}$ Р. Б. Харчук, Сучасна украӥнська література. Постмодерний період, Київ 2008, с. 8

12 Tamże, c. 7. 
śmiewczym zachowaniem i twórczością profanowali przedśmiertny patos konającego imperium", ukazując zwyrodnienie ukraińskiego społeczeństwa jako rezultat dewaluacji radzieckich wartości, i, odpowiednio „dewianostyky” — pokolenie „depresji narodowej” na skutek zapaści gospodarczej, gwałtownego spadku rozwoju rodzimego rynku wydawniczego, kulejącej ukraińskiej demokracji i stałego zagrożenia utraty przez państwo ukraińskie suwerenności), pisarz wskazuje jednocześnie na związek między wskazanymi pokoleniami (tu Danyłenko uwzględnia również pokolenie lat 70.) — wspólną kolonialną spuściznę społeczeństwa ukraińskiego. „Zarówno pokolenie lat 70., jak i pokolenie lat 80, a także pokolenie lat 90., — pisze Danyłenko, - to parafraza na temat „Wyprowadzenia” Portiaka ${ }^{13}$, gdzie pisarzeizgoje ${ }^{14}$ porzucają skażone chorobą kolonializmu społeczeństwo, jednak ich „,wyprowadzenie" okazuje się iluzoryczne, albowiem odbywa się w granicach jednego i tego samego ciemnego pokoju, bez drzwi ${ }^{15}$.

W najnowszym opracowaniu na temat współczesnej prozy ukraińskiej okresu postmodernizmu autorstwa przywołanej wyżej Charczuk, badaczka poszerza klasyfikację o najmłodszą generację ukraińskich twórców. Charczuk, opierając się na znakomitej skądinąd pracy Hundorowej Postczarnobylska biblioteka: ukraińska literacka postmoderna (2005), wyróżnia takie „zręby” ukraińskiego postmodernizmu, jak: neopozytywizm i „neonarodnyctwo” (tzw. pokolenie „ojców” - pisarze debiutujący w latach 60. XX w., do dziś należący do intelektualnego establishmentu, między innymi Jewhen Hucało, Wołodymyr Drozd, Roman Iwanyczuk, Marija Matios), neomodernizm (Medwid', Paszkowski, Ulianenko, Stepan Prociuk - kontynuują tzw. „wysoką literaturę", mitologizują ukraińską tradycję literacką, odrzucając przy tym socrealistyczny kanon), wczesne postmodernistyczne zjawiska (Dibrowa, Żołdak, Leś Poderwiański, Wynnyczuk — „kijowska ironiczna szkoła”, literacki underground czasów totalitaryzmu lat 70. XX w., których utwory ujrzały światło dzienne w latach 90. XX w.), postmodernizm (Andruchowycz, Izdryk, Prochaśko, Jeszkiliew i in. - „Stanisławowski fenomen”, całkowita negacja socrealizmu, neopozytywizmu oraz neonarodnictwa), literatura feministyczna (Zabużko, Kononenko $i$ in.) oraz podlotkowo-dziecięca literatura alternatywna (Serhij Żadan, Irena Karpa, Lubko Deresz, Switłana Powaliajewa, Tania Malarczyk i in.) ${ }^{16}$.

Radykalna zmiana sytuacji geopolitycznej Ukrainy, zmiany mentalne w społeczeństwie oraz pojawienie się literatury postmodernizmu spowodowały, iż przewar-

${ }^{13}$ Wasyl Portiak - ukraiński scenarzysta filmowy, tłumacz, nowelista, należy do pokolenia literackiego lat 80. XX wieku. Swoim niewielkim zbiorem opowiadań $W$ śniegach (2006) zachwycił zarówno krytyków, jak czytelników. „Wielki mistrz małych form”, porównywany do klasyka ukraińskiej noweli Wasyla Stefanyka, podobnie jak ten pisze „krótko i strasznie”. Portiak zwraca się do bolesnej tematyki lat 40 i 50 XX w. na Ukrainie Zachodniej — UPA, NKWS, sztucznego głodu 1933 r. Nowela Wyprowadzenie (czytelna aluzja do biblijnej historii „wyprowadzenia” przez Mojżesza wybranego ludunarodu z Egiptu do ziemi obiecanej) opowiada o wyprowadzeniu z chorego społeczeństwa do źródeł Ciepłej Wody garstki nieskażonych totalitaryzmem ludzi przez Starego — przywódcę bezdomnych. Cel okazuje się iluzoryczny, podobnie jak niekończący się bieg do raju łyżwiarza w czerwonej czapce (personifikacja radzieckich marzeń).

${ }^{14} \operatorname{Izgoj}(u k r$. iзгой) — używana w średniowiecznej Rusi nazwa osób wykluczonych zespołeczeństwa ze względów materialnych. Dotyczyła zarówno chłopów wykluczonych ze swojej gromady wskutek przemian feudalnych, jak i książąt nie posiadających własnej włości i w związku z tym nie posiadających żadnego zabezpieczenia materialnego (zamieszkiwali oni najczęściej na dworach spokrewnionych książąt). Określenia tego zaprzestano używać w XIV wieku.

${ }^{15}$ В. Даниленко, Лісоруб у пустелі. Письменник $і$ літературний процес, Київ 2008, c. $265-266$.

${ }^{16}$ Р. Б. Харчук, Сучасна украӥнська література. Постмодерний період, Київ 2008. 
tościowaniu uległ wizerunek twórcy. Podobnie bowiem jak niezamknięty i niezakończony do dzisiaj proces kształtowania się ukraińskiego postmodernizmu, jego ogromna różnorodność, wizerunek ukraińskiego twórcy również nie jest jednolity.

Jeszcze w roku 1995 w przedmowie do antologii Dziesięciu ukraińskich prozaików Wiaczesław Medwid` konstatował, iż „,ukraiński byt odbiera twórcy siły przeładowaniem wydarzeń, i co za tym idzie niemożnością ich opanowania"17. Zaniepokojenie istniejącym stanem rzeczy odnośnie do ukraińskiej przestrzeni literackiej i sytuacji ukraińskiego twórcy wyrażają krytycy, literaturoznawcy, sami pisarze, podkreślając, iż najnowszej literaturze brak ,ustalonych ocen, niezachwianych autorytetów i wyznaczonego kanonu" ${ }^{18}$, że „wyczuwa się pewną niejasność, niepewność, nieokreśloność wyobrażeń o tym, co dzieje się z nami w literaturze [...]"19 lub też, ze względu na funkcjonowanie literatury w społeczeństwie „cywilizacyjnego rozłamu" na dwie orientacje geopolityczne: euroazjatycką i europejska, rodzi się sytuacja „nieokreśloności, a więc, niepewności, niezdecydowania, co z kolei stwarza społeczną pasywność, brak indywidualnej inicjatywy, pesymistyczne nastroje...”20.

Twórców epoki ,post” interesują nie tyle problemy globalne, co raczej lokalne, nie mas, a przeciwnie - najmniejszy fragment egzystencji — osoba. Dlatego też, zdaniem Charczuk ${ }^{21}$, zasadne jest określenie ich jako „minimalistów”, subiektywizujących potok informacyjny. Rzadziej poszukują prawdy, sprawiedliwości, źródeł zła. Konstatują raczej marginalność, nienormalność, niekiedy potworność. Ich bohaterowie to osoby nietypowe, nierzadko bezwolnie wegetujące w świecie, którym rządzą zło i przemoc. Miłość utożsamiana jest z seksem, co najbardziej uwidocznia się w prozie feministycznej (Badania terenowe nad ukrainskim seksem Zabużko, Rodacy na obczyźnie Kononenko, Umrzyj ze mna Ponomarenko i in.), ale nie tylko (Rekreacje Andruchowycza; Ugoda Ulianenki, Życie haremowe Wynnyczuka; To, co pod spodem Jurija Pokalczuka i in.)

To wszystko daje krytykom podstawę, by twierdzić, iż współcześni ukraińscy twórcy wyznają specyficzną filozofię życia, ,inną estetykę" (Charczuk). Jak zaznacza Danyłenko ${ }^{22}$, podczas gdy lata 30 . ofiarowały literaturze ukraińskiej „Rozstrzelane Odrodzenie", 60. — dysydentów, 70. — pokolenie stróżów, to 80. i 90. — dały pokolenie kloszardów. Pokolenie lat 80 . i 90 . łączy specyficzny kloszardzki styl życia. Z problemem bezdomności borykały się między innymi, takie jaskrawe współczesne osobowości literackie, jak: Jewhen Paszkowski, Wołodymyr Cybulko, Anatolij Szczerbatiuk, Jurko Gudź, Ołeś Ulianenko i in. Paradoksalnie to pozwalało im czuć się wolnymi, a nawet drukować w prestiżowych ukraińskich czasopismach. Według Danyłenki ${ }^{23}$, właśnie status „stróża” czy „kloszarda” dawał szansę pozostania sobą i realizowania siebie jako twórczej osobowości. Przy czym, o ile jeszcze pokolenie literackie lat osiemdziesiatych, jak zaznaczał badacz, to ,bezsilni buntownicy walczący o oczyszczenie człowieka z polipów i liszai chorego społeczeństwa", o tyle pisarze lat 90. XX w. - to ,,pokolenie rejestratorów martwego człowieka, a dokładnie, człowieka z martwym Bogiem w duszy"24. Jeszcze na początku lat dwutysięcz-

17 Десять украӥнських прозаӥків, упоряд., передм., бібліографія, літ. ред. В. Медведя, Київ 1995, c. 3.

18 Р. Харчук, Покоління постепохи, [в:] „Дивослово”, 1998, № 1, с. 6.

${ }^{19}$ Г. Сивокінь, Сучасність украӥнської літератури в історичній перспективі, [в:] „Слово i Час", 2001, № 1, с. 22.

${ }^{20}$ М. Жулинсь кий, На шляху в європейський простір, [в:] „Слово і Час”, 2001, № 1, с. 5.

${ }^{21}$ Р. Харчук, Покоління постепохи.., с. 11.

${ }^{22}$ В. Даниленко, Лісоруб у пустелі.., с. 101.

${ }^{23}$ Tamże, c. 102.

${ }^{24}$ В. Даниленко, Історія одного ісходу.., с. 13. 
nych Żułyński ${ }^{25}$ dyplomatycznie zaznaczając, iż najżywiej na koniec ery literatury w służbie narodu zareagowała młoda ukraińska proza (uczucie beznadziei, nihilizmu, braku perspektyw, „totalne nie” w prozie Ulianenki, Paszkowskiego i in.), ostrzegał jednocześnie przed „niebezpieczeństwem kosmopolitycznej erozji”, utratą własnej kultury, historii, duchowości, własnego obrazu narodowego, negatywnymi skutkami powszechnej na Ukrainie kultury masowej. Kilka lat później, bogatszy o wiedzę z zakresu najnowszej prozy ukraińskiej, Ihor Bondar-Tereszczenko ${ }^{26}$ surowo ocenił najmłodsze pokolenie ukraińskich pisarzy, czemu dał wyraz chociażby w podtytule jednego z artykułów: O latach dwutysięcznych jako zerowych. Zdaniem krytyka, to dzięki najmłodszej generacji ukraińskich pisarzy „sama literatura z równoprawnego podmiotu społecznej interpretacji przeistoczyła się w nieaktualny rodzaj sztuki”". Ukraiński twórca, zdaniem badacza, wpadł w pułapkę ,postmodernistycznej mody i zetknąwszy się z pokusą popularności, zwrócił się w stronę teatru (O. Irwaneć, S. Żadan), muzyki (W. Neborak, J. Andruchowicz), rynku (I. Małkowycz, W. Jaworski) ${ }^{27}$. Podczas gdy pokolenie literackie lat 80. i 90. XX w. wahało się jeszcze w kwestii: „Życie czy literatura? Semantyka czy pragmatyka? Patria czy muerte?”, pisarze XXI wieku nie mają takich wątpliwości. Stan ten krytyk określa mianem „,permanentnego utwierdzania pragmatyzmu w literaturze zerowych lat dwutysięcznych"28. Konkludując, najmłodsze pokolenie ukraińskich twórców (według Danyłenki „to ci, którzy usiłują odnaleźć w sobie zagubionego Boga”29 ): Serhij Żadan — „smutny klaun, punk i rewolucjonista pokolenia bezdomnych" (T. Hundorowa), zafascynowany fenomenem protestu, lecz nie jego istoty", Irena Karpa - energiczna, cyniczna, "nieprzystosowana", Lubko Deresz - przedstawiciel jaskrawej alternatywy pokoleniowej, którego proza „faktycznie nie wychodzi poza ramy literatury masowej”, czy Switłana Powaliajewa - pisarka, która usiłuje z romantyzmem pisać na tematy nieromantyczne: narkotyki, zapuszczone meliny, psychozy i depresje, — to literacka alternatywa, w utworach której tragiczny obraz ukraińskiej młodzieży irytuje nie tyle przez swą infantylność, co raczej z powodu „skupienia się autorów na sobie, natrętnego, banalnego autobiografizmu, jawnego pozerstwa i spekulacji, wreszcie nihilizmu, wobec którego pisarze (pisarki) nie zgłaszają żadnego sprzeciwu"30. Okazało się iż, pierwsze ukraińskie „pełnowartościowe” pokolenie, które nie było poddane zbiorowej hipnozie komunistycznej ideologii, cierpi na postkolonialny kompleks niższości ${ }^{31}$. Być może dlatego Charczuk ${ }^{32}$ konstatuje, iż ostatnimi czasy pojawia się coraz więcej ukraińskich autorów i jest to odwrotnie proporcjonalne do jakości ukraińskiej literatury.

Za nie najlepszą kondycję ukraińskiego pisarza odpowiada, według wielu badaczy, samo państwo ukraińskie. Powszechnie wiadomo, iż ukraińskojęzyczni ukraińscy pisarze - to przysłowiowi „ostatni Mohikanie”, według Danyłenki „ostatni rycerze słowa" ukraińskiego, którzy przy dzisiejszej niesprzyjającej koniunkturze, pisząc po ukraińsku, swą sławę i dostatnie życie poświęcają na ołtarzu ojczyzny. Jednocześnie znane od dawna zjawisko migracji ukraińskich literatów (w szczególności do Rosji) bezsprzecznie zagraża prawidłowemu rozwojowi ukraińskiej literatury. Wśród współczesnych ,ukraińskich legionistów”, jak ich nazywa Wołodymyr

${ }^{25}$ М. Жулинський, На шляху в європейський простір.., с. 4-5.

${ }^{26}$ І.Бондар-Терещен ко, Неоліт: про дев'яності удвохсловах, [в:],„Кур`єр Кривбасу”, 2005, № 192 , c. 208.

${ }^{27}$ Tamże, c. 209-210.

${ }^{28}$ Tamże.

${ }^{29}$ В. Даниленко, Лісоруб у пустелі.., с. 266.

${ }^{30}$ Р. Б. Харчук, Сучасна украӥнська література.., с. 209.

${ }^{31}$ В. Дан иленко, Лісоруб у пустелі.., 266.

${ }^{32}$ Р. Б. Харчук, Сучасна украӥнська література.., с. 234. 
Danyłenko ${ }^{33}$, wystarczy wymienić odnoszących sukcesy fantastów, piszących jednak po rosyjsku i mieszkających na terenie Rosji, takich jak chociażby Maryna i Serhij Diaczenkowie. Stąd też smutny wniosek badacza: gdyby Ukraina po proklamacji niepodległości nie pozostała kulturalną kolonią, gdyby ukraiński pisarz nie czuł się stale poniżany z powodu braku odpowiednich honorariów, umożliwiających mu godne życie, gdyby, wreszcie nie zdemoralizowane społeczeństwo, zapatrzone w nie swoją kulturę, z pewnością mniejsza byłaby fala migracji ukraińskich literatów.

I wreszcie, mocno nadwątlona kondycja ukraińskiego pisarza to skutek braku odpowiedniego audytorium czytelniczego. Oksana Zabużko ${ }^{34} \mathrm{w}$ eseju „Psychologiczna Ameryka" i renesans azjatycki, albo znów o Kartaginie podkreślała, iż chociaż od czasów, gdy przestało istnieć Księstwo Halicko-Wołyńskie, ukraińska państwowość, mimo efektownych sukcesów doby kozackiej i bohaterskiego zrywu w 1918 roku, nie potrafiła osiągnąć dojrzałej, w pełni rozwiniętej i samodzielnej formy, mając status prowincji, to jednak w takich warunkach przez sześć i pół wieku „za cenę ogromnych ofiar, przeraźliwego marnotrawienia bezcennych ludzkich sił”, „za cenę tytanicznej pracy tych prawych jednostek, których dla zbawienia ukraińskiej Sodomy nigdy nie brakowało", pod koniec XX w. mimo wszystko Ukraińcom udało się zachować tożsamość narodową". Przy czym jednym z najpoważniejszych skutków ubocznych 650-letniej nieustannej i duchowo wyczerpującej walki z prowincjonalizmem ukraińskiej kultury było zaistnienie kultury „własnej” i „nie najgorszej”, za to „nikomu nieznanej”, nawet samym Ukraińcom.

Kwestia recepcji ukraińskiej książki wciąż pozostaje palącym problemem na Ukrainie. Z pesymizmem wypowiada się jeden z ukraińskich krytyków: „Kalejdoskop imion, książek, utworów, widniejących na współczesnym ukraińskim horyzoncie literackim pozostaje $\mathrm{w}$ geometrycznej proporcji (!) do malejącego zainteresowania czytelniczego podobnymi zjawiskami"35. Ukraiński czytelnik nie jest przygotowany na ukraińską książkę, zdecydowanie preferuje publikacje w języku rosyjskim. W 1998 roku Charczuk ${ }^{36}$ ze smutkiem konstatowała: „Jesteśmy świadkami oczywistego spadku literackiego [...]" i na potwierdzenie powyższej opinii badaczka przytacza fakty, przedstawione w jednym z artykułów ukraińskiego krytyka i literaturoznawcy Mykoły Riabczuka: w roku 1990 na jedną osobę na Ukrainie przypadało 3,34 książki, w 1996 roku — już tylko 0,996. Dekadę później ta sama badaczka znów porusza kwestię bardzo złej koniunktury czytelniczej, zaznaczając, iż na 46 milionów Ukraińców ukraińskojęzyczne wydania najciekawszych autorów ukazują się w nakładzie po pięć tysięcy egzemplarzy ${ }^{37}$. Natomiast Wołodymyr Danyłenko ${ }^{38}$ dostrzega aż trzynaście cech odpowiedzialnych za złą kondycję ukraińskiego rynku księgarskiego, z których najważniejsze to: kolonialna mentalność Ukraińców, „okupacja” ukraińskiego rynku księgarskiego przez rosyjski biznes wydawniczy, niski autorytet języka ukraińskiego na Ukrainie, poniżający status ukraińskiego pisarza. Dlatego też obecnie, dwadzieścia lat po odzyskaniu przez Ukrainę niepodległości, zdaniem Charczuk ${ }^{39}$, ukraińska literatura nadal pozostaje literaturą postkolo-

${ }^{33}$ В. Даниленко, Лісоруб у пустелі.., с. 50.

${ }^{34}$ O. Zabużko, ,Psychologiczna Ameryka” i renesans azjatycki, albo znów o Kartaginie, [w:] Sny o Europie. Wybór i redakcja O. Hnatiuk, przeł. O. Hnatiuk, K. Kotyńska, R. Rusnak, Kraków 2005, s. 59-60.

${ }^{35}$ Cуt. zа: Г. Си вокінь, Сучасність української літератури в історичній перспективі, [в:] „Слово і Час”, 2001, № 1, с. 27.

${ }^{36}$ Р. Харчук, Покоління постепохи.., с. 8.

${ }^{37}$ Р. Б. Харчук, Сучасна украӥнська література.., с. 234.

${ }^{38}$ В. Даниленко, Лісоруб у пустелі.., с. 64-65.

${ }^{39}$ Р. Б. Харчук, Сучасна украӥнська література.., с. 233. 
nialną, odzwierciedlająca istnienie kolonialnego narodu, który po okresie rusyfikacji i sowietyzacji wciąż próbuje odzyskać własną tożsamość.

Ukraiński twórca przebył drogę od krzewiciela idei narodu, nauczyciela tożsamości narodowej, tworzącego ku pokrzepieniu serc - do twórcy wolnego, korzystającego z wszelkich przywilejów swobody, nie tylko w sensie politycznym, ale i wolności całkowitej. Słusznie bowiem zaznacza Charczuk ${ }^{40}$, iż o ile celem wszystkich ugrupowań literackich XX w. i współtworzących je twórców było uzyskanie państwowości dla Ukrainy i państwowego statusu dla literatury ukraińskiej, o tyle celem twórców epoki ,post” jest „odpaństwowienie” literatury, nie tylko w sensie uwolnienia literatury od nacisku ideologicznego. „Pokolenie epoki ,post”, — zaznacza badaczka, - nie chce takiego nacisku nawet ze strony państwa ukraińskiego" 41.

Choć ukraińscy twórcy posiadają niejedną twarz, co wiąże się z wielogłosowością procesu literackiego, łączy ich poczucie osamotnienia w społeczeństwie, żyjącym chwilą obecną, zmęczonym i nierzadko zrezygnowanym, w społeczeństwie, konsekwentnie pozbawiającym się, jak trafnie zauważył przedwcześnie zmarły pisarz Jurko Gudź, ,reliktowego” czytelnika”. Jeszcze dobitniej ujął to Wołodymyr Danyłenko porównując ukraińskiego pisarza do „drwala na pustyni”.

Rodzi się zatem pytanie, jak w obecnych warunkach, przy takiej niesprzyjającej koniunkturze wydawniczej i czytelniczej funkcjonować ma ukraiński twórca?! Czy możliwe, by spełniło się smutne proroctwo Jurka Gudzia, który szesnaście lat temu, w roku 1995, przewidywał nadejście „stu lat samotności ukraińskiej literatury?" 42.

Wołodymyr Danyłenko z zachwytem tudzież zadziwieniem wspomina wystawę malarstwa prymitywnego pt. Kozak Mamaj, która swego czasu miała miejsce w Muzeum Sztuk Plastycznych w Kijowie. Pisarza zachwyciło ogromne zainteresowanie obrazami legendarnego Mamaja ze strony ukraińskiej inteligencji, która licznie odwiedziła ekspozycję, bardzo żywo na nią zareagowała i na dodatek posługiwała się piękną ukraińszczyzną. To pozwoliło uwierzyć pisarzowi, iż póki Ukraina ma taką wierną publiczność, póty ma przed sobą przyszłość.

Wydaje się, iż analogicznie można to odnieść do współczesnej literatury i funkcjonującego w niej pisarza. Pozostaje więc żywić nadzieję, iż szerokie i, póki co, nie usystematyzowane spektrum areałów literatury ukraińskiej oraz usiłujących w nim przetrwać ukraińskich twórców, pozwoli z czasem stworzyć mozaikowy, co nie znaczy eklektyczny, obraz literacko-artystycznego odzwierciedlenia ruchu ukraińskiej kultury i literatury w stronę europejskiej cywilizacji duchowej przy jednoczesnym zachowaniu własnej odrębności narodowej.

\footnotetext{
${ }^{40}$ Р. Харчук, Покоління постепохи.., с. 7.

${ }^{41}$ Tamże.

${ }^{42}$ Ю. Гудзь, Наприпочатку ста літ самотности, [в:] „Світо-вид”, 1995, № 3, с. 61-65.
} 